\title{
PEMURNIAN MONO-DIASILGLISEROL HASIL ESTERIFIKASI PALM FATTY ACID DISTILLATE DAN GLISEROL DENGAN EKSTRAKSI PELARUT-SAPONIFIKASI DAN DISTILASI MOLEKULER
}

\section{PURIFICATION OF MONO-DIACYLGLYCEROL FROM GLYCEROL AND PALM FATTY ACID DISTILLATE ESTERIFICATION BY SOLVENT EXTRACTION - SAPONIFICATION AND MOLECULAR DISTILLATION}

\author{
Riri Mardaweni ${ }^{1)}$, Dwi Setyaningsih ${ }^{2,3)^{*}}$, dan Meika Syahbana Rusli ${ }^{2}$ \\ ${ }^{1)}$ Program Studi Teknologi Industri Pertanian, Fakultas Teknologi Pertanian, Institut Pertanian Bogor \\ Kampus IPB Darmaga, Bogor 16680 \\ ${ }^{2}$ Departemen Teknologi Industri Pertanian, Fakultas Teknologi Pertanian, Institut Pertanian Bogor \\ ${ }^{3)}$ Surfactant and Bioenergy Research Center, LPPM-IPB \\ E-mail: dwisetya.sbrc@gmail.com
}

Makalah: Diterima 25 Juli 2016; Diperbaiki 8 Februari 2017; Disetujui 15 Februari 2017

\begin{abstract}
Mono-diacylglycerol (M-DAG) is one of potential palm oil derived products to be developed. Palm Fatty Acid Distillate (PFAD) and glycerol esterification using Methyl Ester Sulfonic Acid (MESA) catalyst produced M-DAG that consist of Free Fatty Acid (FFA) and Triacylglycerol (TAG) fractions. FFA and TAG fractions can reduce the $M-D A G$ emulsifier quality. Therefore, purification process is needed to eliminate FFA and TAG fractions. The purpose of this research was to improve the M-DAG emulsifier quality by purification process. The purification was performed in two ways: solvent extraction - saponification and molecular distillation. Solvent extraction - saponification was done with the addition of 0, 10, 15 and 20\% (w/w) $\mathrm{NaHCO}_{3}$. The result showed that the addition of $20 \%(\mathrm{w} / \mathrm{w}) \mathrm{NaHCO}_{3}$ was the best treatment. It was able to produce $43.52 \%$ yield of M-DAGconsisted of $44.48 \%$ Thin-Layer Chromatography (TLC) in FFA+TAG composition, $31.05 \%$ MAG, 24.47\% DAG, melting point of $44.83^{\circ} \mathrm{C}$, free fatty acid level of $19.43 \%$, pH value of 6 , emulsion stability of $51.21 \%$ for 12 hours, has a white color, dry texture, and odorless. The molecular distillation at temperature of $100-180^{\circ} \mathrm{C}$ on purification process was carried out to separatethe FFA. Molecular distillation had produced distillate and residue. Molecular distillation was an effective process to separate the FFA from M$D A G$ whereas produced $96.09 \%$ of FFA from distillation flow.
\end{abstract}

Keywords : glycerol, molecular distillation, palm fatty acid distillate, purification, saponification

\section{ABSTRAK}

Mono-diacylglyserol (M-DAG) merupakan salah satu produk turunan minyak sawit yang potensial untuk dikembangkan. Proses esterifikasi Palm Fatty Acid Distillate (PFAD) dan gliserol dengan bantuan katalis methyl ester sulfonic acid (MESA) menghasillkan mono-diacylglyserol (M-DAG) yang mengandung fraksi asam lemak bebas (ALB) dan triasilgliserol (TAG). Fraksi asam lemak bebas (ALB) dan triasilgliserol (TAG) dapat menyebabkan penurunan kualitas dari emulsifier mono-diacylglyserol (M-DAG). Oleh karena itu, untuk menghilangkan fraksi asam lemak bebas (ALB) dan triasilgliserol (TAG) dilakukan proses pemurnian. Penelitian ini bertujuan untuk meningkatkan mutu emulsifier mono-diacylglyserol (M-DAG) dengan proses pemurnian. Proses pemurnian dilakukan dengan 2 cara yaitu ekstraksi pelarut - saponifikasi dan distilasi molekuler. Ekstraksi pelarut - saponifikasi dilakukan dengan penambahan $\mathrm{NaHCO}_{3} 0,10,15$, dan $20 \%$ (b/b). Perlakuan terbaik dihasilkan dengan penambahan $\mathrm{NaHCO}_{3} 20 \%(\mathrm{~b} / \mathrm{b})$, dimana kondisi tersebut menghasilkan karakteristik mono-diacylglyserol (M-DAG) dengan rendemen 43,52\%, komposisi asam lemak bebas (ALB)+triasilgliserol (TAG) dengan kromatografi lapis tipis (KLT) 44,48\%, MAG 31,05\%, DAG 24,47\%, titik leleh 44,83 ${ }^{\circ} \mathrm{C}$, kadar asam lemak bebas $19,43 \%$, nilai pH 6 , stabilitas emulsi 51,21\% selama 12 jam, memiliki warna putih, tekstur kering dan tidak berbau. Proses pemurnian dengan distilasi molekuler dilakukan untuk pemisahan fraksi asam lemak bebas (ALB) pada suhu distilasi $100-180^{\circ} \mathrm{C}$. Distilasi molekuler memiliki output yaitu distilat dan residu. Hasil penelitian menunjukkan distilasi molekuler efektif untuk memisahkan asam lemak bebas, dimana pada aliran distilat menghasilkan kadar asam lemak bebas sebesar 96,09\%.

Kata kunci : distilasi molekuler, gliserol, saponifikasi, pemurnian, palm fatty acid distillate

\section{PENDAHULUAN}

Produksi minyak sawit mentah (CPO) Indonesia mengalami peningkatan setiap tahunnya.
Menurut Kementerian Perindustrian tahun 2015 produksi CPO mencapai 32,5 juta ton dan diperkirakan Indonesia akan memproduksi 40 juta ton CPO pada tahun 2020. 
Salah satu produk turunan CPO yang memiliki nilai ekonomis relatif tinggi dan mempunyai prospek pasar yang baik adalah monodiacylglyserol (M-DAG). M-DAG termasuk jenis emulsifier yang paling banyak digunakan dalam industri pangan dengan status GRAS (generally recognized as safe) atau aman untuk dikonsumsi. MDAG merupakan surfaktan non-ionik sebagai bahan pengemulsi dan penstabil pada produk-produk pangan dan kosmetika (Hasenhuettl, 2008).

M-DAG dapat diproduksi dengan cara proses esterifikasi gliserol dan asam lemak bebas (O’Brien, 2009). Gliserol dapat diperoleh dari hasil samping produksi biodiesel. Menurut Ahn et al. (1995) produksi biodiesel menghasilkan residu cukup besar yaitu kurang lebih $12 \%$ dari produk berupa gliserol kasar yang masih mengandung sisa katalis, dan zat pengotor lainnya sehingga perlu dilakukan pemurnian sebelum digunakan untuk produksi M-DAG.

Salah satu sumber asam lemak bebas yang dapat digunakan untuk sintesis M-DAG adalah palm fatty acid distillate (PFAD). PFAD dapat diperoleh dari hasil samping proses pemurnian CPO. Proses esterfikasi asam lemak bebas dan gliserol secara kimia dapat menggunakan katalis kimia. Katalis kimia yang digunakan adalah methyl ester sulfonic acid (MESA) yang merupakan katalis asam. Penggunaan bahan kimia dikarenakan bernilai lebih ekonomis daripada penggunaan enzim dan memerlukan waktu reaksi yang lebih singkat.

M-DAG yang dihasilkan dari proses esterifikasi tersebut masih mengandung fraksi asam lemak bebas (ALB) dan triasilgliserol (TAG) yang dapat menyebabkan penurunan kualitas produk MDAG sebagai bahan baku emulsifier yaitu dapat menurunkan kemampuan M-DAG dalam mengemulsikan minyak dan lemak serta ketahanan M-DAG dalam mempertahankan emulsi yang telah terbentuk. Oleh karena itu, harus dilakukan proses pemisahan fraksi ALB dan TAG tersebut. Metoda yang digunakan untuk proses pemurnian M-DAG dapat dilakukan dengan metode ekstraksi pelarut saponifikasi dan distilasi molekuler (Irimescu et al., 2001). Saponifikasi basa dapat dilakukan dengan basa lemah dan basa kuat. Namun, penggunaan basa kuat tidak hanya melarutkan fraksi ALB, akan tetapi dapat juga melarutkan sebagian M-DAG. Oleh karena itu digunakan saponifikasi dengan basa lemah yaitu $\mathrm{NaHCO}_{3}$. Proses pemurnian M-DAG juga dilakukan dengan distilasi molekuler. Metode ini diharapkan dapat memisahkan fraksi ALB yang terkandung dalam M-DAG. Distilasi molekuler merupakan metode distilasi yang banyak digunakan untuk pemisahan dan pemurnian pada komponen yang tidak stabil terhadap panas serta untuk cairan atau bahan dengan tekanan uap rendah dan berat molekul tinggi (Micov et al., 1997 dalam Fregolente et al., 2007).
Penelitian ini bertujuan untuk meningkatkan mutu emulsifier M-DAG dengan proses pemurnian. Selain itu, untuk melihat pengaruh penambahan $\mathrm{NaHCO}_{3}$ terhadap karakteristik M-DAG yang dihasilkan dengan metoda ekstraksi pelarut - saponifikasi serta membandingkan karakteristik M-DAG tersebut dengan hasil proses pemurnian menggunakan distilasi molekuler.

\section{BAHAN DAN METODE}

\section{Bahan dan Alat}

Bahan yang digunakan dalam penelitian adalah palm fatty acid distillate (PFAD) dari PT. Asianagro Agungjaya, gliserol kasar dan katalis methyl ester sulfonic acid (MESA) dari SBRC LPPM - IPB, asam fosfat teknis $85 \%$, zeolit, heksan teknis, etanol $96 \%, \mathrm{NaHCO}_{3}$.

Alat yang digunakan berupa reaktor dengan kapasitas $25 \mathrm{~L}$, filtrasi, alat vacuum distilasi, saringan vakum, kertas saring Whatman 41, magnetic stirrer, refrigerator, dan distilasi molekuler. Alat analisis berupa gas chromatography - mass spectrometry (GC-MS) Agilent 1909IS-433, lempeng KLT, buret, neraca analitik, peralatan gelas, corong, sudip, pipet tetes, tanur, oven, desikator, penangas air, termometer, pipa kapiler dan kertas $\mathrm{pH}$ universal.

\section{Tahapan Penelitian \\ Pemurnian Gliserol Kasar}

Gliserol kasar dimasukkan ke dalam reaktor pemurnian dengan kondisi proses pada suhu $75^{\circ} \mathrm{C}$, kecepatan pengadukan $300 \mathrm{rpm}$, pada saat suhu $55^{\circ} \mathrm{C}$ dilakukan penambahan asam fosfat $85 \%$ sebanyak $5 \%(\mathrm{v} / \mathrm{v})$, pengadukan dalam reaktor terus berlangsung selama 2 jam (Farobie, 2009). Setelah itu campuran didinginkan dan didiamkan selama 1 jam. Selanjutnya dilakukan settling dan difiltrasi. Kemudian untuk menghilangkan air dan metanol dilakukan menggunakan vacum distilasi pada suhu $130^{\circ} \mathrm{C}$, tekanan -25 in $\mathrm{Hg}$, kecepatan pengadukan $300 \mathrm{rpm}$ dan waktu proses selama 2 jam, sehingga diperoleh gliserol murni $>90 \%$.

\section{Karakterisasi Bahan Baku}

Analisis yang dilakukan pada gliserol sebelum dan setelah pemurnian (SNI 06-1564-1995) yaitu uji kadar gliserol, kadar abu, nilai $\mathrm{pH}$, dan warna, sedangkan analisis yang dilakukan pada PFAD yaitu uji kadar asam lemak bebas, titik leleh, dan nilai $\mathrm{pH}$.

\section{Sintesis dan Karakterisasi M-DAG \\ Proses sintesis M-DAG dilakukan menggunakan metode Hermanda (2015) yang dimodifikasi. Proses dimulai dengan mereaksikan gliserol dan PFAD dengan perbandingan rasio mol 1:2 serta katalis MESA $1,5 \%$ pada reaktor berpengaduk kapasitas $25 \mathrm{~L}$ secara vakum,}


kemudian dipanaskan selama 75 menit pada suhu $120^{\circ} \mathrm{C}$, setelah itu dilakukan penambahan zeolit sebanyak 5\% (b/b). Karakteristik M-DAG kasar yang dihasilkan berupa kadar asam lemak bebas, titik leleh, nilai pH, kadar abu, uji GC-MS, analisis kromatografi lapis tipis (KLT), warna, bau dan tesktur.

\section{Pemurnian M-DAG dengan Ekstraksi Pelarut - Saponifikasi}

Proses pemurnian dilakukan dengan metode ekstraksi pelarut - saponifikasi Bashir (2014) yang dimodifikasi. Proses pemurnian bertujuan untuk memisahkan M-DAG, ALB dan TAG. TAG diekstraksi menggunakan pelarut dan ALB disabunkan dengan basa. Proses pemurnian dilakukan pada suhu ruang yang diawali dengan melarutkan $30 \mathrm{~g}$ sampel M-DAG kasar dalam 150 $\mathrm{mL}$ pelarut heksan dan etanol, dimana rasio heksan dan etanol 1:1 kemudian diaduk selama 5 menit. Selanjutnya ditambahkan $\mathrm{NaHCO}_{3}$ dengan perlakuan $0,10,15$, dan $20(\mathrm{~b} / \mathrm{b})$ pengadukan dilanjutkan dengan magnetic stirrer selama 10 menit. Sampel yang telah disaponifikasi tersebut didiamkan dan dipisahkan dari endapan sabun yang terbentuk. Fraksi heksan dan fraksi etanol yang tercampur didinginkan dalam refrigerator untuk kristalisasi selama 24 jam. Selanjutnya sampel disaring untuk mendapatkan M-DAG murni dengan kertas saring Whatman 41 menggunakan penyaring vakum, kemudian sampel dikering anginkan untuk menguapkan pelarut yang tersisa. Analisis dan karakterisasi M-DAG murni yang dilakukan yaitu rendemen, kadar asam lemak bebas, titik leleh, kadar abu, stabilitas emulsi, nilai pH, uji GC-MS, analisis KLT, dan karakteristik secara visual.

Rancangan percobaan yang digunakan adalah rancangan acak lengkap (RAL) satu faktor yaitu penambahan natrium karbonat dengan 4 taraf dan 3 kali ulangan. Data yang dihasilkan kemudian diolah menggunakan Anova dengan $\mathrm{P}<0,05$ dilanjutkan dengan uji Duncan dengan software IBM Statistic SPSS22.

\section{Pemurnian M-DAG dengan Destilasi Molekuler} Proses pemurnian dengan distilasi molekuler yang dimodifikasi dari Martin et al. (2005) bertujuan untuk melakukan pemisahan ALB dalam M-DAG. M-DAG kasar terlebih dahulu dilelehkan untuk mendapatkan campuran cairan yang homogen. Kondisi proses distilasi molekuler yang dilakukan yaitu suhu evaporator $100-180^{\circ} \mathrm{C}$, kecepatan wiper, tekanan vakum, suhu umpan dan suhu kondensor masing-masing tetap yaitu $350 \mathrm{rpm}$, $30-50 \mathrm{pa}, 50^{\circ} \mathrm{C}$, dan $60^{\circ} \mathrm{C}$. Analisis M-DAG yang dilakukan berupa kadar asam lemak bebas, titik leleh, nilai $\mathrm{pH}$, stabilitas emulsi, uji GC-MS, analisis KLT, dan karakteristik secara visual.

\section{HASIL DAN PEMBAHASAN}

\section{Pemurnian Gliserol Kasar}

Pemurnian gliserol kasar dimulai dengan pencampuran gliserol kasar dalam reaktor berkapasitas $20 \mathrm{~L}$ dengan kecepatan $300 \mathrm{rpm}$, suhu $75^{\circ} \mathrm{C}$. Pada saat suhu $55^{\circ} \mathrm{C}$ dilakukan penambahan asam fosfat, kemudian pencampuran dilanjutkan selama 2 jam. Penambahan asam fosfat bertujuan untuk mengikat sisa katalis $\mathrm{KOH}$ sehingga membentuk garam $\mathrm{K}_{3} \mathrm{PO}_{4}$ yang berwujud padat, selain itu juga bertujuan untuk mengubah sabun yang terbentuk menjadi asam lemak bebas. Asam fosfat sebagai pereaksi dapat menghidrolisis senyawa sabun dan menetralisir katalis yang digunakan dalam reaksi transesterifikasi produksi biodiesel sehingga gliserol terpisah dari garam dan sabun terlarut. Penambahan asam fosfat menyebabkan terbentuknya tiga lapisan yang tidak saling bercampur yang terdiri dari lapisan atas yaitu asam lemak, lapisan tengah yaitu gliserol, serta lapisan bawah yaitu garam $\mathrm{K}_{3} \mathrm{PO}_{4}($ Gambar 1).

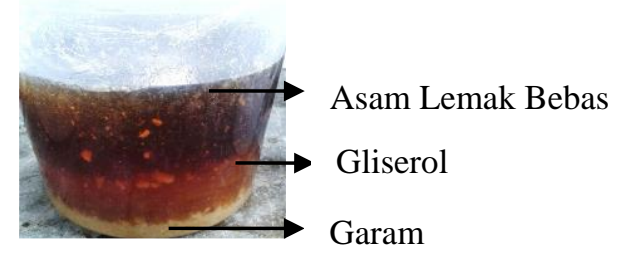

Gambar 1. Tiga lapisan yang terbentuk setelah penambahan asam fosfat

Untuk memisahkan gliserol, ALB dan garam yang terbentuk kemudian dilakukan filtrasi sehingga dihasilkan gliserol dengan tingkat kemurnian atau kadar gliserol $\pm 80 \%$. Gliserol hasil filtrasi dilakukan pemisahan metanol dan air yang masih tersisa dengan menggunakan vacum distilasi pada suhu $130^{\circ} \mathrm{C}$ untuk mendapatkan tingkat kemurnian gliserol yang tinggi. Menurut Diwani et al. (2009) sisa metanol yang diuapkan pada suhu $>65^{\circ} \mathrm{C}$ dapat meningkatkan kemurnian gliserol hingga $85 \%$. Gliserol hasil pemurnian dilakukan pengujian dan dibandingkan dengan gliserol sebelum pemurnian. Perbandingan hasil analisis karakteristik gliserol sebelum dan sesesudah pemurnian dapat dilihat pada Tabel 1 .

Kadar gliserol merupakan parameter penting dalam menentukan tingkat kemurnian gliserol. Peningkatan kadar gliserol disebabkan karena netralisasi basa dan pemecahan sabun yang dapat membebaskan gliserol dari garam dan asam lemak bebas. Semakin tinggi nilai kadar gliserol maka semakin tinggi tingkat kemurnian gliserol. Berdasarkan SNI 06-1564-1995, kadar gliserol minimum yang diperbolehkan untuk dikomersialkan adalah $80 \%$. Dari segi warna gliserol kasar memiliki warna yang lebih gelap dibandingkan warna gliserol murni. Semakin tinggi kadar gliserol, maka warna gliserol akan semakin terang. 
Tabel 1. Hasil analisis gliserol kasar dan gliserol murni

\begin{tabular}{lccc}
\hline Jenis Uji & Gliserol Kasar & Gliserol Murni & SNI 06-1564-1995 \\
\hline Kadar Gliserol (\%) & 40 & 97 & Min 80 \\
Kadar Abu (\%) & 5,52 & 0,92 & Maks. 10 \\
Nilai pH & 11 & 6 & - \\
Warna & Coklat kehitaman & Coklat & - \\
\hline
\end{tabular}

Selain kadar gliserol, kadar abu merupakan salah satu parameter penting dalam menentukan kualitas gliserol. Jika kadar abu semakin rendah maka kandungan zat mineral atau anorganik pada gliserol semakin menurun sehingga tingkat kemurnian gliserol juga akan meningkat.

Nilai $\mathrm{pH}$ gliserol kasar lebih tinggi dibandingkan dengan gliserol setelah pemurnian. Gliserol kasar memiliki nilai $\mathrm{pH}$ 11. Nilai pH tinggi disebabkan karena masih banyak mengandung katalis $\mathrm{KOH}$ dan sabun kalium, sedangkan gliserol murni memiliki nilai $\mathrm{pH}$ 4. Gliserol setelah pemurnian mengalami penurunan disebabkan karena dalam proses pemurniannya menggunakan asam fosfat $85 \%$, sehingga menyebabkan ion kalium dari katalis $\mathrm{KOH}$ yang bersifat basa berikatan dengan ion fosfat dan membentuk garam kalium fosfat, sedangkan sabun terpecah menjadi asam lemak bebas dan garam.

Selain gliserol, bahan baku lain yg digunakan dalam penelitian ini adalah PFAD. PFAD merupakan hasil samping dari pemurnian CPO setelah melalui tahapan proses degumming, deasidifikasi dan pengeringan sistem vakum. Hasil analisis karakteristik PFAD dapat dilihat pada Tabel 2.

Tabel 2. Hasil analisis PFAD

\begin{tabular}{lcc}
\hline Jenis Uji & Hasil & SNI 01-0015-1987 \\
\hline Kadar ALB & $87,76 \%$ & Min. 80\% \\
Titik leleh & $39^{\circ} \mathrm{C}$ & - \\
Nilai pH & 4 & - \\
\hline
\end{tabular}

PFAD pada suhu ruang berbentuk padat dan berwarna kuning kecoklatan, sedangkan ketika dipanaskan akan berubah menjadi warna coklat tua. Asam lemak yang banyak terkandung dalam PFAD adalah asam palmitat $(47,58 \%)$, asam oleat $(34,75 \%)$, asam linoleat $(10,35 \%)$, dan asam stearat $(5,14 \%)$ (Atmadja, 2000). Kadar asam lemak dalam bahan baku merupakan faktor penentu dalam efektifitas proses reaksi esterifikasi M-DAG. PFAD memiliki nilai $\mathrm{pH}$ rendah yang disebabkan karena tingginya kadar asam lemak sehingga dapat digunakan sebagai sumber asam lemak bebas dalam pembuatan M-DAG.

PFAD memiliki titik leleh $39^{\circ} \mathrm{C}$, titik leleh minyak dan lemak dipengaruhi oleh asam lemak penyusunnya. PFAD memiliki kandungan asam lemak jenuh yang tinggi berupa asam palmitat $\left(\mathrm{C}_{16} \mathrm{H}_{32} \mathrm{O}_{2}\right)$ dan asam lemak tak jenuh berupa asam oleat $\left(\mathrm{C}_{18} \mathrm{H}_{38} \mathrm{O}_{2}\right)$, sehingga titik lelehnya relatif tinggi. Asam lemak jenuh mempunyai titik leleh yang lebih tinggi dari pada asam lemak tidak jenuh, karena ikatan antar molekul asam lemak tidak jenuh kurang kuat dibandingkan asam lemak jenuh. Makin panjang rantai atom $\mathrm{C}$, titik leleh akan semakin tinggi dan sebaliknya semakin banyak jumlah ikatan rangkapnya maka titik leleh akan semakin menurun.

\section{Karakterisasi M-DAG kasar}

Proses esterifikasi pada penelitian dilakukan dengan mereaksikan PFAD dan gliserol menggunakan bantuan katalis asam yaitu katalis MESA. Hasil analisis M-DAG kasar dapat dilihat pada Tabel 3 .

Tabel 3. Hasil analisis M-DAG kasar

\begin{tabular}{lc}
\hline Jenis Uji & Hasil \\
\hline Kadar ALB $(\%)$ & 41,82 \\
Titik leleh $\left({ }^{\circ} \mathrm{C}\right)$ & 40 \\
Kadar Abu $(\%)$ & 0,11 \\
Nilai pH & 4 \\
Warna & Coklat \\
Tekstur & Padat \\
Bau & Berbau \\
\hline
\end{tabular}

Tingginya kadar ALB pada M-DAG kasar disebabkan karena adanya asam lemak bebas yang tidak bereaksi dengan gliserol saat proses reaksi esterifikasi. Semakin tinggi kadar ALB dari M-DAG kasar maka titik leleh akan semakin rendah. Titik leleh merupakan suhu pada saat suatu bahan berubah dari fase padat menjadi cair hingga keseluruhan menjadi cair sempurna (O’Brien, 2009). M-DAG kasar memiliki nilai pH 4, hal ini disebabkan karena proses esterifikasi dengan bantuan katalis MESA yang bersifat asam, sehingga menyebabkan M-DAG kasar memiliki $\mathrm{pH}$ yang rendah. M-DAG kasar memiliki warna coklat, karena proses sintesis $\mathrm{M}$ DAG pada suhu tinggi yaitu $120^{\circ} \mathrm{C}$, dan tingginya asam lemak bebas pada M-DAG kasar yang dihasilkan menyebabkan M-DAG kasar berbau dan sedikit berminyak, sehingga perlu dilakukan proses pemurnian untuk mengurangi ALB dan TAG yang masih terkandung dalam M-DAG kasar.

\section{Karakteristik M-DAG Setelah Pemurnian dengan Ekstraksi Pelarut - Saponifikasi}

Proses pemurnian bertujuan untuk mengurangi kandungan ALB dan TAG yang terdapat pada M-DAG. Analisis Karateristik MDAG setelah proses pemurnian dapat dilihat pada Tabel 4 
Tabel 4. Karakteristik M-DAG setelah proses pemurnian dengan ekstraksi pelarut - saponifikasi

\begin{tabular}{lcccccc}
\hline \multirow{2}{*}{ Perlakuan } & \multicolumn{5}{c}{ Karakteristik M-DAG } \\
\cline { 2 - 6 } & $\begin{array}{c}\text { Rendemen } \\
(\%)\end{array}$ & $\begin{array}{c}\text { Kadar ALB } \\
(\%)\end{array}$ & $\begin{array}{c}\text { Titik Leleh } \\
(\mathbf{\%})\end{array}$ & $\begin{array}{c}\text { Nilai } \\
\text { pH }\end{array}$ & $\begin{array}{c}\text { Kadar } \\
\text { Abu (\%) }\end{array}$ & $\begin{array}{c}\text { Stabilitas } \\
\text { Emulsi (\%) }\end{array}$ \\
\hline $\mathrm{NaHCO}_{3} 0 \%$ & $66,51^{\mathrm{d}}$ & $29,56^{\mathrm{d}}$ & $37,50^{\mathrm{a}}$ & $5^{\mathrm{a}}$ & $0,16^{\mathrm{a}}$ & $27,34^{\mathrm{a}}$ \\
$\mathrm{NaHCO}_{3} 10 \%$ & $52,76^{\mathrm{c}}$ & $21,54^{\mathrm{c}}$ & $42,50^{\mathrm{b}}$ & $5^{\mathrm{a}}$ & $0,55^{\mathrm{b}}$ & $42,76^{\mathrm{b}}$ \\
$\mathrm{NaHCO}_{3} 15 \%$ & $47,07^{\mathrm{b}}$ & $19,93^{\mathrm{b}}$ & $44,00^{\mathrm{c}}$ & $6^{\mathrm{b}}$ & $1,33^{\mathrm{c}}$ & $45,82^{\mathrm{bc}}$ \\
$\mathrm{NaHCO}_{3} 20 \%$ & $43,52^{\mathrm{a}}$ & $19,43^{\mathrm{a}}$ & $44,83^{\mathrm{d}}$ & $6^{\mathrm{b}}$ & $1,46^{\mathrm{d}}$ & $51,21^{\mathrm{c}}$ \\
\hline
\end{tabular}

Keterangan: huruf berbeda menunjukkan perlakuan berpengaruh nyata terhadap respon pada taraf nyata $5 \%$

Tabel 4 menunjukkan bahwa penambahan $\mathrm{NaHCO}_{3}$ memberikan pengaruh nyata terhadap rendemen, kadar asam lemak bebas, titik leleh, dan kadar abu pada taraf nyata $5 \%$. Rendemen M-DAG setelah pemurnian bervariasi dari $43,52 \%$ sampai $66,51 \%$. Rendemen pada perlakuan $\mathrm{NaHCO}_{3} \quad 0 \%$ memberikan pengaruh berbeda nyata terhadap masing-masing perlakuan dengan penambahan $\mathrm{NaHCO}_{3} 10,15$, dan $20 \%$ (b/b). Semakin tinggi konsentrasi penambahan $\mathrm{NaHCO}_{3}$, maka rendemen M-DAG yang dihasilkan akan semakin rendah. Hal ini menunjukkan bahwa penambahan $\mathrm{NaHCO}_{3}$ tidak hanya menyabunkan ALB, tetapi dapat menyabunkan sebagian dari M-DAG. Selain itu, rendemen yang tinggi dapat juga disebabkan oleh tingginya kadar asam lemak dari M-DAG. Hasil kadar asam lemak bebas setelah pemurnian dengan saponifikasi basa dan ekstraksi pelarut bervariasi dari $19,43 \%$ sampai $29,56 \%$. Kadar asam lemak bebas pada $\mathrm{NaHCO}_{3} 0 \%$ berbeda nyata dengan perlakuan penambahan $\mathrm{NaHCO}_{3} 10$, 15, dan $20 \%$ (b/b). Semakin tinggi konsentrasi penambahan $\mathrm{NaHCO}_{3}$ maka kadar asam lemak bebas semakin rendah. Hal ini disebabkan karena dengan penambahan $\mathrm{NaHCO}_{3}$ proses saponifikasi berjalan secara spesifik dalam menyabunkan ALB namun variasi jumlahnya tidak terlihat berpengaruh secara signifikan. Menurut Ketaren (2008) semakin rendah jumlah ALB maka kualitas M-DAG yang dihasilkan semakin baik.

Setiap emulsifier mempunyai titik leleh tertentu tergantung titik leleh asam lemak pembentuk emulsifier (Hassenhuattl, 2008). Uji titik leleh setelah pemurnian dengan saponifikasi basa dan ekstraksi pelarut bervariasi dari $37,50^{\circ} \mathrm{C}$ sampai $44,83^{\circ} \mathrm{C}$. Titik leleh pada $\mathrm{NaHCO}_{3} 0 \%$ berbeda nyata dengan penambahan $\mathrm{NaHCO}_{3} 10,15$, dan $20 \%$ (b/b). Semakin tinggi konsentrasi penambahan $\mathrm{NaHCO}_{3}$ maka titik leleh M-DAG semakin tinggi. Hal ini disebabkan karena penambahan $\mathrm{NaHCO}_{3}$ yang semakin tinggi menyebabkan kandungan asam lemak bebas semakin rendah, sehingga titik leleh MDAG akan semakin tinggi. Menurut Winarno (2002), asam lemak jenuh mempunyai titik leleh yang lebih tinggi daripada asam lemak tidak jenuh, karena ikatan antar molekul asam lemak tidak jenuh tidak stabil. Bentuk trans pada asam lemak akan menyebabkan asam lemak mempunyai titik leleh lebih tinggi daripada asam lemak bentuk cis.
Pengukuran nilai pH bertujuan untuk mengetahui tingkat keasaman produk M-DAG. MDAG sebelum pemurnian memiliki nilai $\mathrm{pH} 4$, sedangkan setelah pemurnian dengan saponifikasi basa dan ekstraksi pelarut memiliki $\mathrm{pH}$ berkisar antara 5 dan 6. Nilai pH M-DAG tanpa penambahan $\mathrm{NaHCO}_{3}$ tidak berbeda nyata dengan nilai $\mathrm{pH}$ MDAG pada penambahan $\mathrm{NaHCO}_{3} 10 \%$ (b/b) tetapi memberikan pengaruh berbeda nyata pada nilai $\mathrm{pH}$ dengan penambahan $\mathrm{NaHCO}_{3} 15$ dan $20 \%$ (b/b), sedangkan nilai $\mathrm{pH}$ dengan penambahan $\mathrm{NaHCO}_{3}$ $15 \%(\mathrm{~b} / \mathrm{b})$ tidak berbeda nyata dengan penambahan $\mathrm{NaHCO}_{3} 20 \%$ (b/b). Hal ini menunjukkan bahwa seiring dengan penambahan $\mathrm{NaHCO}_{3}$ maka nilai $\mathrm{pH}$ akan meningkat karena $\mathrm{NaHCO}_{3}$ bersifat basa. Nilai pH pada M-DAG setelah pemurnian sesuai dengan nilai $\mathrm{pH}$ dari GMS komersil yang memiliki $\mathrm{pH} 6$. Tinggi rendahnya $\mathrm{pH}$ juga dapat disebabkan oleh kandungan ALB yang terdapat pada produk. Tingginya asam lemak bebas pada produk akan menurunkan nilai $\mathrm{pH}$.

Pengukuran kadar abu bertujuan untuk mengetahui besarnya kandungan mineral yang terdapat dalam M-DAG. M-DAG setelah pemurnian dengan saponifikasi basa dan ekstraksi pelarut memiliki kadar abu yang bervariasi dari $0,16 \%$ sampai $1,46 \%$. Kadar abu pada $\mathrm{NaHCO}_{3} 0 \%$ berbeda nyata dengan penambahan $\mathrm{NaHCO}_{3} 10,15$, dan $20 \%$ (b/b). Semakin tinggi konsentrasi penambahan $\mathrm{NaHCO}_{3}$ maka kadar abu M-DAG semakin tinggi. Hal ini disebabkan karena $\mathrm{NaHCO}_{3}$ termasuk senyawa kelompok garam, sehingga menyebabkan peningkatan kadar abu.

Karakteristik selanjutnya yang dilakukan adalah stabilitas emulsi. Uji stabilitas emulsi bertujuan untuk mengetahui seberapa lama dan efektif pengemulsi atau emulsifier dalam mempertahankan dan mencampurkan dalam sistem emulsi. Pengujian stabilitas emulsi dilakukan dengan mencampurkan minyak dan air dengan rasio volume yang sama, serta ditambahkan dengan sampel MDAG sesudah pemurnian, kemudian dilakukan pengadukan sampai homogen menggunakan stirrer selama 15 menit. Setelah pengadukan maka akan terbentuk tiga lapisan yaitu lapisan atas (minyak), lapisan bawah (air), dan lapisan tengah (bagian yang teremulsi).

Berdasarkan Tabel 4, M-DAG memiliki stabilitas emulsi berkisar antara 27,34 - 51,21\% 
selama 12 jam. Stabilitas emulsi M-DAG dengan penambahan $\mathrm{NaHCO}_{3} 10 \%(\mathrm{~b} / \mathrm{b})$ tidak berbeda nyata dengan stabilitas emulsi M-DAG pada penambahan $\mathrm{NaHCO}_{3} 15 \%$ (b/b) tetapi memberikan pengaruh berbeda nyata dengan penambahan $\mathrm{NaHCO}_{3} 10$ dan $20 \%$ (b/b), sedangkan stabilitas emulsi dengan penambahan $\mathrm{NaHCO}_{3} 15 \%$ (b/b) tidak berbeda nyata dengan penambahan $\mathrm{NaHCO}_{3} \quad 20 \% \quad$ (b/b). Rendahnya stabilitas emulsi ini dipengaruhi oleh tingginya fraksi ALB yang terkandung dalam MDAG. Fraksi ALB yang tinggi dalam M-DAG dapat menurunkan kinerja M-DAG sebagai pengemulsi.

Daya kerja emulsifier terutama disebabkan oleh bentuk molekulnya yang dapat terikat baik pada minyak maupun air. M-DAG termasuk jenis emulsifier non-ionik yaitu emulsifier yang tidak memiliki muatan ion, tetapi memiliki struktur molekul yang terdiri dari bagian hidrofilik pada gugus -OH dan bagian lipofilik pada gugus ester asam lemak. Karakter lipofilik menyebabkan MDAG memiliki sifat yang sangat baik sebagai emulsifier water in oil, seperti yang dibutuhkan pada pembuatan margarin. Pada suhu ruang, M-DAG tidak larut dalam air dan hanya memiliki kelarutan yang sangat terbatas dalam minyak, kecuali pada suhu tinggi (O’Brien, 2009).

\section{Karakterisasi M-DAG setelah Pemurnian Dengan Distilasi Molekuler}

Metoda lain yang dapat digunakan untuk proses pemurnian M-DAG salah satunya adalah dengan metode destilasi molekuler. Destilasi molekuler merupakan teknik pemisahan dan pemurnian pada komponen yang tidak stabil terhadap panas serta untuk cairan atau bahan dengan tekanan uap rendah. Proses distilasi molekuler bekerja berdasarkan sifat penguapan molekul, dimana kemudahan menguapnya tergantung dari tekanan uap untuk masing-masing molekul tersebut. Tekanan uap setiap molekul berbeda-beda tergantung bobot dari masing-masing molekul tersebut. Parameter penting untuk menunjang proses pemisahan M-DAG dengan destilasi molekuler adalah berat molekul dan titik didih.

Proses pemurnian dengan destilasi molekuler sampel terlebih dahulu dicairkan pada suhu $100^{\circ} \mathrm{C}$, kemudian bahan baku dipanaskan pada suhu $170-180^{\circ} \mathrm{C}$. Destilasi molekuler menghasilkan dua fraksi yaitu residu dan destilat. Residu merupakan bahan yang tidak terdestilasi, sedangkan destilat adalah hasil dari destilasi. Pemurnian dengan destilasi molekuler dilakukan bertujuan untuk memisahkan asam lemak bebas dari produk MDAG.

Berdasarkan hasil penelitian dapat diketahui bahwa fraksi asam lemak bebas terdapat di dalam destilat, sedangkan di dalam residu merupakan M-DAG yang tidak terdestilasi. Terhadap hasil destilat dan residu kemudian dilakukan analisa karakterisasinya.

Tabel 5 menunjukkan karakteristik M-DAG setelah pemurnian dengan destilasi molekuler. Kadar asam lemak bebas yang diperoleh dari hasil residu dan destilat masing-masing adalah sebesar $25,12 \%$ dan 96,09\%. Hal ini menunjukkan bahwa fraksi asam lemak bebas lebih tinggi terdapat pada destilat. Kadar asam lemak bebas pada destilat lebih tinggi karena asam lemak bebas lebih mudah menguap dibandingkan dengan fraksi MAG dan DAG. Menurut Posada (2007), semakin tinggi suhu evaporator maka semakin banyak komponen yang masuk ke fase destilat/terdestilasi. Pada penelitian ini komponen yang terdestilasi pada suhu $180^{\circ} \mathrm{C}$ adalah asam lemak bebas, sedangkan hasil residu merupakan komponen yang tidak menguap seperti MAG dan DAG karena memiliki titik uap diatas $200^{\circ} \mathrm{C}$. Menurut Martin et al. (2005), pada suhu destilasi $160-180^{\circ} \mathrm{C}$ dapat menghilangkan asam lemak bebas lebih dari $90 \%$.

M-DAG setelah pemurnian dengan destilasi molekuler memiliki titik leleh pada destilat $38^{\circ} \mathrm{C}$ dan residu $25^{\circ} \mathrm{C}$, nilai $\mathrm{pH}$ masing-masing 4 , dan stabilitas emulsi selama 12 jam masing-masing sebesar 14,29 dan $23,57 \%$. Hasil analisa ini menunjukkan bahwa hasil residu tidak mengalami perubahan kualitas pada titik leleh, nilai $\mathrm{pH}$, dan stabilitas emulsi selama proses pemurnian dengan destilasi molekuler.

\section{Analisis Gas Chromatography-Mass Spectrometry (GC-MS)}

Pengujian dilakukan dengan alat GC-MS. Hasil uji kromatografi gas kemudian dianalisis dengan menggunakan software GC-MS data analisis untuk memperoleh komposisi asam lemak yang terkandung dalam M-DAG. Sampel yang digunakan dalam pengujian GC-MS yaitu sampel M-DAG kasar, M-DAG setelah pemurnian dengan penambahan $\mathrm{NaHCO}_{3} 20 \%$ (b/b), dan M-DAG dengan proses distilasi molekuler. Hasil pengujian GC-MS dapat dilihat pada Tabel 6.

Tabel 5. Karakteristik M-DAG hasil proses pemurnian dengan distilasi molekuler

\begin{tabular}{lcccc}
\hline & \multicolumn{4}{c}{ Karakteristik M-DAG } \\
\cline { 2 - 5 } Sampel & Kadar ALB (\%) & Titik Leleh $\left({ }^{\circ} \mathbf{C}\right)$ & Nilai pH & Stabilitas Emulsi (\%) \\
\hline Distilat & 96,09 & 38 & 4 & 14,29 \\
Residu & 25,12 & 25 & 4 & 23,57 \\
\hline
\end{tabular}


Tabel 6. Hasil analisis GC-MS terhadap M-DAG

\begin{tabular}{|c|c|c|c|c|c|}
\hline \multirow[b]{2}{*}{$\begin{array}{c}\text { tR } \\
\text { (menit) }\end{array}$} & \multirow[b]{2}{*}{ Nama Senyawa } & \multicolumn{4}{|c|}{$\%$ Luas Area } \\
\hline & & $\begin{array}{c}\text { M-DAG } \\
\text { Kasar }\end{array}$ & $\begin{array}{c}\text { M-DAG } \\
\text { Murni }\end{array}$ & Residu & Distilat \\
\hline 6,83 & Gliserin & 0,55 & - & - & - \\
\hline 14,06 & Heptadekanon & 0,06 & - & - & - \\
\hline 14,19 & Metil Palmitat & 1,30 & 0,65 & - & \\
\hline 14,86 & Asam Palmitat & 43,56 & 20,17 & 25,55 & 68,46 \\
\hline 15,38 & Metil Oleat & 6,86 & 6,40 & - & - \\
\hline 15,54 & Asam Oleat & - & - & 23,88 & - \\
\hline 15,78 & Etil Oleat & 0,34 & 0,16 & 0,98 & 0,13 \\
\hline 20,41 & 9,17- Octadecadienal & 3,81 & - & - & - \\
\hline
\end{tabular}

Berdasarkan uji GC-MS di atas dapat dilihat bahwa M-DAG kasar memiliki fraksi ALB yang berupa asam palmitat dengan luas area $43,56 \%$. Sedangkan M-DAG setelah pemurnian dengan $\mathrm{NaHCO}_{3} 20 \%$ (b/b) memiliki fraksi ALB yang berupa asam palmitat dengan luas area $20,17 \%$, pemurnian dengan distilasi molekuler pada residu memiliki fraksi ALB berupa asam palmitat dengan luas area $25,55 \%$, asam oleat $23,88 \%$, sedangkan pada distilat berupa asam palmitat dengan luas area 68,46\%. M-DAG (MAG dan DAG) yang dihasilkan dengan uji GC-MS pada saat sebelum dan sesudah proses pemurnian tidak dapat teridentifikasi. Senyawa yang teridentifikasi dengan uji GC-MS adalah fraksi asam lemak bebas, hal ini diduga karena pada kondisi alat GC-MS dengan initial temperature $290^{\circ} \mathrm{C}$, pressure $17,71 \mathrm{Psi}$, dan run time selama 35 menit tidak cukup untuk mengidentifikasi senyawa MAG dan DAG yang terdapat pada campuran M-DAG setelah pemurnian.

\section{Analisis Kromatografi Lapis Tipis (KLT)}

Analisis KLT dilakukan bertujuan untuk mengetahui jumlah komposisi MAG, DAG, TAG dan ALB. Perhitungan secara kuantitatif luas area dari fraksi -fraksi yang terkandung dalam M-DAG yang diperoleh dengan cara analisis menggunakan software ImageJ. Hasil persentase (spot faraksi) MDAG setelah pemurnian dapat dilihat pada Tabel 7.

Berdasarkan perhitungan persentase pada Tabel 7 dapat dilihat bahwa M-DAG sebelum dan setelah pemurnian memiliki komposisi ALB+TAG, $\mathrm{MAG}$, dan DAG yang bervariasi. Analisis dengan KLT merupakan salah satu teknik kromatografi sederhana yang dapat memisahkan campuran lemak dan minyak berdasarkan perbedaan polaritas dalam sekali elusi. Menurut Hamilton dan Rossel (1987), thin-layer chromatography/kromatografi lapis tipis (KLT) merupakan salah satu teknik kromatografi sederhana yang dapat memisahkan campuran minyak dan lemak yang memiliki perbedaan polaritas dalam sekali elusi. Adanya perbedaan kepolaran tersebut memberikan pengaruh perbedaan jarak spot-spot atau nilai rf (nilai jarak yang ditempuh senyawa dari titik asal) pada TLC Silica Gel 60 F254.
Campuran pelarut yang digunakan untuk mengelusi adalah petroleum eter, dieteil eter dan asam asetat glasial dengan perbandingan 90:10:1 $(\mathrm{v} / \mathrm{v} / \mathrm{v})$, dengan campuran pelarut tersebut masingmasing fraksi dapat dipisahkan berdasarkan polaritasnya. Fraksi yang bersifat lebih non-polar akan terelusi terlebih dahulu, sedangkan fraksi yang bersifat lebih polar akan tertahan lebih lama oleh adsorben yang juga bersifat polar. Triasilgliserol adalah fraksi yang bersifat lebih nonpolar dibandingkan fraksi lainnya (ALB, DAG, dan MAG) sehingga pada saat pengembangan triasilgliserol akan terelusi pada bagian atas lempeng TLC dan disusul berturut-turut oleh ALB, DAG dan MAG. Pada penelitian ini fraksi ALB dan TAG tidak terelusi secara sempurna sehingga membentuk spot yang menyatu.

Menurut O'Brien (2009), M-DAG komersial memiliki kandungan MAG yang bervariasi yaitu $40 \%$, 50\%, dan $90 \%$ tergantung proses produksinya. Emulsifier dengan komposisi MAG tinggi lebih ideal, karena MAG dapat larut dengan sempurna dalam lemak minyak dan terdispersi dalam air pada kondisi tertentu (Gunstone et al., 1994). Pada Tabel 7 dapat dilihat bahwa komposisi MAG setelah proses pemurnian dengan ekstraksi pelarut - saponifikasi yaitu 31,05\%.

\section{KESIMPULAN DAN SARAN}

\section{Kesimpulan}

Proses pemurnian dapat meningkatkan kualitas M-DAG yang disintesis melalui proses esterifikasi PFAD dan gliserol dengan bantuan katalis MESA. Penambahan NaHCO3 berpengaruh nyata terhadap rendemen, kadar asam lemak bebas, titik leleh, dan kadar abu pada taraf nyata $5 \%$. Perlakuan terbaik pada proses pemurnian tersebut yaitu penambahan $\mathrm{NaHCO}_{3} 20 \%$ (b/b). Kondisi ini menghasilkan karakteristik M-DAG dengan rendemen 43,52\%, luas area ALB dengan GC-MS $20,17 \%$, titk leleh $44,83^{\circ} \mathrm{C}$, kadar asam lemak bebas $19,43 \%$, nilai $\mathrm{pH} 6$, stabilitas emulsi $51,21 \%$ selama 12 jam, komposisi MAG 31,05\%, DAG 24,47\%, ALB+TAG 44,48\%, serta memiliki karakteristik fisik secara visual dengan warna putih, kering dan tidak berbau. 
Tabel 7. Persentase (spot fraksi) M-DAG

\begin{tabular}{lccc}
\hline & \multicolumn{3}{c}{ Komposisi (\%) } \\
\cline { 2 - 4 } \multicolumn{1}{c}{ Sampel } & MAG & DAG & ALB+TAG \\
\hline M-DAG kasar & 26,67 & 22,79 & 50,54 \\
M-DAG murni & 31,05 & 24,47 & 44,48 \\
Residu & 25,29 & 18,19 & 56,51 \\
Distilat & - & 2,66 & 97,34 \\
\hline
\end{tabular}

Pemisahan ALB sangat efektif dilakukan dengan distilasi molekuler dengan kadar ALB 96,09\% dan pada aliran residu memiliki kadar ALB $25,12 \%$, namun masih memiliki tingkat kemurnian M-DAG yang rendah.

\section{Saran}

Untuk penelitian selanjutnya proses pemurnian dengan distilasi molekuler sebaiknya menggunakan suhu yang lebih tinggi dalam proses pemisahan MAG dan DAG serta mencari kondisi proses yang sesuai, sehingga dapat diperoleh kemurnian M-DAG yang lebih tinggi.

\section{DAFTAR PUSTAKA}

Ahn E, Koncar M, Mittelbach M, Marr R. 1995. A low-waste process for the production of biodiesel. Separation Science and Technol. 10 (7-8): 2021-2023.

Atmadja AAAMRD. 2000. Studi pemurnian dan karakterisasi emulsifier campuran mono dan diasilgliserol yang diproduksi dari distilat asam lemak minyak sawit dengan teknik esterifikasi enzimatis menggunakan lipase Rhizomucor miehei. [Skripsi]. Bogor : Institut Pertanian Bogor.

Bashir BA. 2014. Pengaruh rasio etanol dan air serta konsentrasi $\mathrm{NaOH}$ pada pemurnian monodiasilgliserol. [Skripsi]. Bogor : Institut Pertanian Bogor.

Diwani GE, Attia NK, dan Hawash SI. 2009. Development and evaluation of biodiesel fuel and by-products from jatropha oil. International Journal Environment Science. 6 (2) : 219-224.

Fregolente LV, Fregolente PBL, Chicuta AM, Batistella CB, Maciel FR, Maciel MRW. 2007. Effect of operationg conditions on the concentration of monoglycerides using moleculer distillation. Chemical Engineering Research and Design. 85 (A11): 1524-1528.
Gunstone FD, Harwood JL, dan Padley FB. 1994. The Lipid Handbook. London: Chapman and Hall.

Hamilton RJ dan Rossell JB. 1987. Analysis of oils and fats. England (GB): Elsevier Science.

Hasenhuettl GL. 2008. Food Emulsifiers and Their Applications. Editor Hasenhuettl dan Hartel. New York (USA) : Springer Science.

Hermanda A. 2015. Sintesis mono-diasilgliserol berbasis gliserol dan palm fatty acid distillate. [Skripsi]. Bogor : Institut Pertanian Bogor.

Irimescu R, Furihata K, Hata K, Iwasaki Y, Yamane T. 2001. Two step enzymatic synthesis of docosahexaenoic acid-rich symmetrically structured triacylglycerol via 2monoacylglycerols. Journal America Oil Chemical Soc. 78:743-748.

Ketaren S. 2008. Pengantar Teknologi Minyak dan Lemak Pangan. Jakarta: UI Press.

Martin PF, Ito VM, Batistella CB, Maciel MRW. 2005. Free fatty acid separation from vegetable oil deodorizer distillate using molekuler distillation process. Separation and Purification Technology (48) : 78-84.

O'Brien RD. 2009. Fats and Oil: Formulating and Processing for Application. Edisi ke-3. Boca Raton (US): CRC Pr.

Posada LR, Shi J, Kakuda Y, Xue SJ. 2007. Extraction of tocotrienols from palm fatty acid distillates using moleculer distillation. Separation and Purification Technology (57) : 220-229.

[SNI] Standar Nasional Indonesia. 1995. SNI 061564-1995: Gliserol Kasar. Jakarta: SNI.

Winarno FG. 2002. Kimia Pangan dan Gizi. Penerbit Gramedia Pustaka Utama. Jakarta. 